\title{
Methods in Lexicography and Dictionary Research*
}

\author{
Stefan J. Schierholz, Department Germanistik und Komparatistik, \\ Friedrich-Alexander-Universität Erlangen-Nürnberg, Germany \\ (Stefan.Schierholz@fau.de)
}

\begin{abstract}
Methods are used in every stage of dictionary-making and in every scientific analysis which is carried out in the field of dictionary research. This article presents some general considerations on methods in philosophy of science, gives an overview of many methods used in linguistics, in lexicography, dictionary research as well as of the areas these methods are applied in.
\end{abstract}

Keywords: SCIENTIFIC METHODS, LEXICOGRAPHICAL METHODS, THEORY, METALEXICOGRAPHY, DICTIONARY RESEARCH, PRACTICAL LEXICOGRAPHY, LEXICOGRAPHICAL PROCESS, SYSTEMATIC DICTIONARY RESEARCH, CRITICAL DICTIONARY RESEARCH, HISTORICAL DICTIONARY RESEARCH, RESEARCH ON DICTIONARY USE

Opsomming: Metodes in leksikografie en woordeboeknavorsing. Metodes word gebruik in elke fase van woordeboekmaak en in elke wetenskaplike analise wat in die woordeboeknavorsingsveld uitgevoer word. In hierdie artikel word algemene oorwegings vir metodes in wetenskapfilosofie voorgelê, 'n oorsig word gegee van baie metodes wat in die taalkunde, leksikografie en woordeboeknavorsing gebruik word asook van die areas waarin hierdie metodes toegepas word.

Sleutelwoorde: WETENSKAPLIKE METODES, LEKSIKOGRAFIESE METODES, TEORIE, METALEKSIKOGRAFIE, WOORDEBOEKNAVORSING, PRAKTIESE LEKSIKOGRAFIE, LEKSIKOGRAFIESE PROSES, SISTEMATIESE WOORDEBOEKNAVORSING, KRITIESE WOORDEBOEKNAVORSING, HISTORIESE WOORDEBOEKNAVORSING, NAVORSING OP WOORDEBOEKGEBRUIK

\section{Introduction}

In dictionary production and in scientific work which is carried out in the field of dictionary research, methods are used to reach certain results. Currently there is no comprehensive and up-to-date documentation of these particular methods in English. The article of Mann and Schierholz published in Lexico-

* This article is based on the article from Mann and Schierholz published in Lexicographica 30 (2014). The English version was presented on the StellenLex conference 2015 in Stellenbosch organized by Rufus Gouws. Thanks to Laura Schierholz who was an excellent and reliable help in proofreading in order to get the final English version of this text. 
graphica 30 gives an overview in German and is a first attempt to structure the existing methods in our discipline. The other articles which are published in the Lexicographica yearbook (2014) treat methods in specific areas: the functional perspective (Tarp 2014), dictionary planning of online-dictionaries (Geyken 2104), research in dictionary use (Müller-Spitzer 2014b), the saving of lexical data (Romary and Witt 2014), translation science (Bielińska 2014), specialized lexicography (Bocorny Finatto 2014), pronunciation dictionaries (Hirschfeld and Stock 2014), items giving the paraphrase of meaning (Töpel 2014a).

Even this article cannot give a complete overview of all the methods but it provides a general overview of methods in lexicography and dictionary research, as well as in contiguous disciplines. Selected methods will be described in detail to show how to apply the methods.

The basic aim of this article is to foster the work on methods and to encourage young researchers to show more interest in the methods of this research field.

An overview of all methods should be theory independent or should be orientated to the different lexicographical theories, i.e. the "Lexicography and Dictionary Research" (Wiegand 1998a) or the "Function Theory" (Bergenholtz and Tarp 2002; Tarp 2008; Tarp 2013). Above this, all methods which are used in lexicographical practice should be enumerated and ordered. This is rather complicated because one has to keep in consideration that some methods will be applied only with a special dictionary type or are only specific to one dictionary project.

Besides this aspect regarding methods, it has to be noted that the individual theories are not critically reviewed with respect to existing methods, in "Lexicography and Dictionary Research", in the "Function Theory"1, and in "Lexicography as an Art and Craft" (Landau 1989). Exceptions are (a) the Historical Dictionary Research and (b) the Research on Dictionary Use where in the past the state of the art of the empirical methods was summarized by Ripfel and Wiegand (1988), in Wiegand (1998a: 568ff.), in Welker (2006, 2013a, 2013b). For the period from 1993 to 2012 a very good overview of the research projects concerning the use of electronic dictionaries including a lot of critical comments on the used methods is given by Töpel (2014b).

Apart from these observations regarding the documentation of methods, one can find methods reflected more or less in the publications of lexicography. These are the publications where (a) the subject matter itself is methodology, (b) single methods are discussed critically, (c) specific methods are used aligned to the subject matter, $(\mathrm{d})$ methods are applied without any reflection on their use but also without any consequences for the quality of the research results.

\section{What a method is}

A method is a procedure or a technique used to reach a certain aim. In all sciences, scientific methods are applied. They are part of a general theory of sci- 
ence on its own or of theories of an individual science. In general, what all methods have in common is that they are considered as single scientific procedures which serve to gain secured and verifiable insights into scientific objects and entities. ${ }^{2}$ Accordingly, this counts also for methods in metalexicography and also for all the methods in practical lexicography. Wiegand (2010: 251) writes: "A method is an ordered set of instructions to act which have to be followed in at least one orderly sequence and in compliance with the conditions of correctness which are part of the method properties in order to receive the desired result." 3

Starting from the basic elements in science theories you can transfer principles - e.g. observational adequacy, explanatory adequacy, hypothesizing, theory construction (and sub theory construction), methods, application - to theories which are used in a single discipline. For metalexicography, different theories are necessary but a dominant role is played by an action theory and a linguistic theory.

The action theory plays a decisive role for the subject "dictionary" because dictionaries are produced for the purpose of being used. Therefore, the actions of a potential user of a dictionary are in the center of the considerations (cf. Wiegand 1987). An extensive explanation especially in context with the research on dictionary use is found in Wiegand (1998a: 268ff.) but also in the function theory of the Aarhus group (cf. Tarp 2008: 33ff.; Tarp 2014: 58ff.).

The linguistic theory plays a decisive role since, not only in language dictionaries but also in subject dictionaries, linguistic expressions are described in/ with linguistic terms.

In both theories one will find methods that can be considered as inductive (from single propositions, observations or data leading to general insights) or deductive (starting from a general regularity to a statement about a single case). This can be seen from the perspective of the philosophy of science but also from the single sciences (research on dictionary use, linguistics etc.). In German linguistics, this was discussed extensively by weighing up the different positions (cf. among others Schaeder 1981: 28ff.), and it is convincingly demonstrated that the strict separation between "inductive" and "deductive" cannot be kept if the specific features of the subject matter language and the special requests for lexicography are included.

From a single science perspective a differentiated way of looking at things is necessary. Thus, it is better to speak of a primarily inductive method when a systematically collected huge amount of data and the formulation of the hypotheses are used in combination during the research process (cf. Schaeder 1981: 45ff.; Schierholz 2001: 76ff.).

The following methods shall be considered to be used in practical lexicography and in metalexicography. All of them should be guided by the enumerated principles which are universal in general philosophy science. The following text will not contain:

- the field of teaching methods in dictionary use where you can learn the 
skills in dictionary use because these methods belong to the area of didactics.

- the methods which belong to terminology and terminography because this would go beyond the scope of this contribution.

- scientific methods in practical lexicography.

Firstly, a short overview to the methods in linguistics will be given because these methods play a dominant role in the production of linguistic lexicographical items.

\section{Methods in Linguistics}

Within philosophy of science the theories and methods in linguistics can be distinguished under the aspects of the differentiations described above. Very often, a classification in the qualitative and the quantitative approach can be found in linguistics, which takes into account more the specific properties of the subject matter. In this case the mutual dependence of both approaches is absolutely necessary (cf. Schlobinski 1996: 15ff.).

Qualitative methods are procedures in which data measurable in numbers are primarily not collected (e.g. linguistic descriptions and explanations), and in which new insights are obtained from critical hermeneutical work, e.g. by the processes of comprehension and interpretation. Methods of data collection include interviews, written questionnaires, and observations. For the recording and interpretation of these data, special tools were developed for example, content analysis, text analysis, conversation analysis or discourse analysis (cf. Deppermann 2008; Warnke and Spitzmüller 2008). Qualitative methods are also the classical ones in traditional grammar, such as elimination tests, permutation tests or commutation tests.

Quantitative methods are always aligned with data which are measurable in numbers and which are collected with the aim to assess a judgment which is based on results presented in numbers. The data collection must underlie a systematic method of gathering the data. Koplenig (2014: 65f.) distinguishes between "obtrusive" and "unobtrusive methods". Another distinction can be made between experimental and non-experimental procedures. Many of the tools of data survey and data evaluation used are adapted from empirical social sciences and are taken over into linguistics (e.g. oral and written questionnaires, observations, tests, experiments, probabilistic statistics), other tools have on a larger scale genuine linguistic properties (e.g. the query to and the evaluation of text corpora) (cf. the summary in Albert and Marx 2010: 12ff.; Meindl 2011: 25ff.; with a perspective from social sciences e.g. Bortz and Döring 2006 and fundamental Diekmann 2007).

All linguistic procedures play a dominant role in lexicography and dictionary research (cf. Rundell 2012: 64ff.). If such linguistic data are collected it 
shall be the basis for the writing of lexicographical items. This means that one has to consider;

(a) the procedures of phonetic transcription, procedures of segmentation and classification, many procedures in phonology and morphology, procedures to categorize the parts of speech, syntactical procedures for the categorization of valence partners, procedures of meaning analysis, content analysis, prototype theory and many more (cf. Rundell 2012: 67ff.);

(b) the methods of observation and questioning, statistical procedures for the collection of linguistic data, for the evaluation of huge and small data sets, for samples as well as for the selection from huge data sets (e.g. text corpus data) (cf. amongst others Schlobinski 1996; Albert and Koster 2002; Albert and Marx 2010);

(c) the knowledge the lexicographer has from experience related to their profession.

The methods of corpus linguistics must be used with special attention because linguistic data is collected on the basis of huge text corpora. ${ }^{4}$ The required size of the corpus, the balance of the corpus, the state of the corpus (original text or scanned text; with annotation or current text), the text varieties which exist in the corpus; but first the query procedures and the procedures of the citation evaluation must be taken into consideration and must be used with a critical reflection and perspective to the investigation aims (cf. Heid 2008, Lemnitzer and Zinsmeister 2006, Schierholz 2008a, Schierholz 2008b, Schierholz 2013). It must also be distinguished in the lexicographical process between corpus controlled, corpus supported or corpus validated (cf. amongst others Engelberg and Lemnitzer 2009: 238).

Attention must be paid to the use of linguistic methods in that they serve very often only for the material processing and material preparation for the following lexicographical process. In each case it must be decided in which way data extracted from natural language sources have to be further worked on in the lexicographical process with linguistic methods.

\section{Methods in Lexicography and Dictionary Research}

Lexicography and dictionary research is marked by pluralism of methods: The lexicographical work is determined by the type of the dictionary but reverts to the results, the methods and the theories of different sciences. ${ }^{5}$ (Wiegand 1984: 559; cf. also Wiegand 1998a: 100).

The methods are (a) linguistic methods which are used for the collection of the linguistic data, (b) methods which source from social sciences and especially psychology (e.g. quantitative data analysis, systematic empirical methods, case studies), (c) furthermore philological methods, in which the introspection 
together with the personal language competence is important, (d) the methods of comprehension and interpretation which are adapted to the text material but also to all empirical data. Even the philological methods have to fulfill the condition that the intersubjective examination of the results must be possible in each part of the workflow.

In the following section, typical methods and their application in either practical lexicography or in the sub theories of dictionary research will be presented with the essential features.

\subsection{Methods in Practical Lexicography}

During dictionary-making, different phases of the lexicographical process can be distinguished (cf. Gouws and Prinsloo 2005: 9ff., Svensén 1993). Wiegand (1998a: 134ff.) calls (a) the phase of preparation, (b) the acquisition of the material and the data, (c) the treatment of the material and the data, (d) the evaluation of the material and the data, (e) the preparation of the print process; Engelberg and Lemnitzer (2009: 228) complete with (f) the phase of further development, as well as the upkeeping and cultivation of the data material. In each of the phases different decisions must be taken, actions must be done and different methods must be used. The phases are valid for print dictionaries and for online dictionaries; in some areas in the same way, in others not (cf. Klosa 2013 about online-dictionaries). Furthermore, it must be determined whether the production of a dictionary is (a) a complete new project, (b) a dictionary derived from one or more existing dictionaries, (c) a translation of another dictionary, (d) a revision and/or actualization of an existing edition or a retrodigitalization. The latter one can be done by copying (e.g. double-keyingmethod) or scanning with text recognition (cf. Piotrowski 2012: 25-52; Burch et al. 2000 to the example of $D W B$ ), or by parsing the tape of type setting instructions (cf. Hauser and Storrer 1996), where the digitalized data (automatically or semi-automatically) can be transferred into single data (e.g. in XML) or into a data base system (cf. also Engelberg and Lemnitzer 2009: 223ff.).

In the following section the methods and the application area where methods must be used will be enumerated in connection with the phases of the lexicographical process. ${ }^{7}$ All cases will be led from a complete new production of a dictionary. Only some methods will be dealt with in detail.

\subsubsection{Methods during the preparation phase}

In the preparation and planning phase of the lexicographical process a needs analysis must be done to calculate the costs, the work flow, the agreed time period of the making and the size of the dictionary. To this belongs an evaluation of the market opportunities, a calculation of production costs, the personal planning, the time management, the development of a payment system and the 
profit prospects (cf. Beltrami 2013). To be able to do this one needs methods from business management, which have to be selected and applied with consideration of the dictionary type, the users of the dictionary, as well as the size and the structure of the dictionary (cf. Engelberg and Lemnitzer 2009: 227ff.).

If a dictionary is made by an editorial staff, it is necessary to have a work schedule of the lexicographical work, in which the distribution of the tasks is arranged, e.g. the conditions of the compilation of the articles and the distribution of the articles to the lexicographers: (a) It is possible that each article is written completely only by one person. The sequence of the article writing can start with the articles under $A$, continuing onto the initials of the word list until $Z$. (b) It is possible that a lexicographer will write only one item type or a set of item types in every article so that the production of item types is done thematically. The approach under (a) - from $A$ to $Z-$ as it was practiced in many dictionary projects in the last centuries, has very often the consequence that the lemma list under $A$ is excessively long and that also the dictionary articles are more extensive i.e. produced more carefully and with a bigger expenditure of time than the lemma list under Z (cf. Schierholz and Windisch 1991). The more specialist field knowledge that is necessary for specific items of the dictionary articles the better it is when single item types are worked on by a lexicographer who is an expert in the respective special field. The methods which should be used here to achieve an efficient work flow are very different and their availability may depend on the financial situation and on the economic behavior of the dictionary producer. Furthermore the methods belong to the procedures which are used in the section of work organization and they are based on experience and knowledge but they have nearly nothing to do with any linguistic method. Instead of that, all these processes should be carried out in cooperation with an experienced lexicographer because the experience from the lexicographical workplace is helpful and necessary to organize the work efficiently.

Another part of the preparation phase is the development of a concrete dictionary conception where the dictionary type and the dictionary functions are laid down; these decisions also influence other decisions on methods (cf. part 4.1.8). Besides, a text compound structure and a data distribution programme in which the distribution of the lexicographical data and the components of the text compound are arranged must be developed. Apart from the data distribution in the wider sense the following aspects concerning methods must be arranged, although some corrections are possible in some cases later on (cf. also Schierholz and Wiegand 2004):

- the way of the article arrangement in the word list and/or in registers or indices, where alphabetical arrangement and thematic arrangement have to be distinguished fundamentally: in the case of an alphabetical order one has to choose a method of alphabetization, where especially the filling of alphabet external signs must be taken into account (cf. Wiegand 1989: 376ff.; Wiegand and Beer 2013; Wiegand and Gouws 2013). In the 
case of a thematic arrangement, not only a system of concepts or of subject groups must be determined, but also a fitting method how the lemma signs or rather dictionary entry can be categorized systematically in this system (cf. to this complex of problems amongst others Wiegand 2004: 62*ff.; Quasthoff 2004: 199*ff.).

- the microstructural programme and the microstructural method of lexicographical treatment (e.g. integrated, not-integrated, semi-integrated) (cf. amongst others Wiegand and Smit 2013a)

- the use of textual condensation procedures (cf. amongst others Wolski 1989), of abbreviations, symbols etc.

- the utilization of transcription methods and transliteration methods with corresponding tables etc.

- guidelines for the drawing up of items giving the paraphrase of meaning (e.g. Wahrig 1973)

- the reference prerequisites and the mediostructural programme which describes under which circumstances and in how a reference carrying out can be undertaken (cf. amongst others Wiegand 2002a; Wiegand and Smit 2013b)

- the layout and the typographical marking up of all dictionary components, especially for the dictionary articles with their items and structural indicators.

Also the working tools (software) to be used must be committed (cf. part 4.1.8) because homogeneous methods must be applied for the sake of uniform results concerning the form. All the methods relevant for the lexicographer to make a dictionary in a systematic procedure should be written down in an instruction book $^{8}$.

On the basis of these decisions, example articles should be produced so that the practical suitability of the instructions can be tested and the instruction book can be corrected and possibly changed. Consequently, example articles can function in the following working phases as best example articles for the dictionary work.

\subsubsection{Methods during the phase of material collection}

In the phase of the material collection the lexicographical work is based on the experience and knowledge of the staff members and on general search routines, which are used to collect data from the internet, from libraries or from existing dictionaries. These processes will help to provide the sources for building up the dictionary basis, which is distinguished into the primary sources (data which are used for the purpose of the dictionary making, e.g. citation 
collections, special text corpora), the secondary sources (other dictionaries), and the tertiary sources (all other linguistic material concerning the dictionary subject matter (e.g. literature, grammars) (cf. amongst others Wiegand 1998a: 140; Schierholz and Wiegand 2004: 208f.). Reichmann (1990: 1589) takes the secondary sources and the tertiary sources together. The collection of these data must be done systematically in order to make the data stock of the dictionary basis reliable.

In the case of a new compilation of a corpus for the linguistic analysis and even in the case of the takeover of an existing corpus, the method of compiling (representative, balanced, opportunistic, see above, section 3) must be applied in a very critical manner. Subsequent to this the data can be tagged or annotated so that methods (programs, algorithms) of natural language processing will be used (cf. Klosa 2013: 521).

If in the planned dictionary images and diagrams or in the case of electronic dictionaries, audio and video examples should be presented, it is necessary to compile a data collection which is determined by clear criteria and by methods, which can ensure the suitability of the multimedia material for the envisaged dictionary type and for the dictionary functions.

\subsubsection{Methods in the phase of material processing}

The phase of the material processing is in the traditional lexicographical process the use of the note catalogue and the excerption of recently obtained material (to the procedure cf. Wiegand 1998a: 145ff.). In case of the - nowadays usual - use of big electronic corpora, other methods are necessary. In the case of the data volume being oversized, the data must be analyzed automatically and by random principle. However, if the data volume is a manageable size each piece of data should be analyzed individually.

For this phase Klosa (2013: 521) mentions the process of corpus analysis for the sake of the extraction of lemma candidates, word frequencies and collocation candidates (to the procedures of statistical determining of collocations cf. Evert 2005). The methodical backgrounds of the lemma selection will be demonstrated more precisely in the next step.

\section{The method of lemma selection}

Before one starts writing dictionary articles, a lemma candidate list must be drawn up (cf. amongst others Bergenholtz (1989; 1995); Bergenholtz and Meder (1998); Drosdowski (1977); Scholze-Stubenrecht (2002)). This list should be an open list so that during the process of dictionary production new lemmata can be entered. The lemma selection must ensure a well-balanced distribution of the lemmata over the individual character stretches.

The distribution of the lemmata in accordance with the character stretches 
should correspond to the distribution of the token and the distribution of the types in a certain natural language. The quantitative proportion which the word forms have per initial in one language can be recorded by the frequency distributions of word forms in text corpora (cf. amongst others Schierholz and Windisch 1991). In the production of a specialized dictionary a corpus with texts of the special field in question should be the basis because specialized vocabulary can have another distribution of the lemmata per initial than the distribution of the general vocabulary. In dictionaries the page volume which is at hand for a single character stretch should be distributed analogous to the lemma quantities because only then can a homogeneous dealing with the dictionary articles concerning the quantitative perspective be assumed (cf. also Engelberg and Lemnitzer 2009: 246ff.).

These quantitative analyses must be completed by examinations with regard to the contents in case of a general qualitative judgment. In the end, the lexicographer must decide which words or which lexicographical items should be estimated as important for a dictionary. During this process one has to take into account other criteria such as the dictionary type, characteristics of special field vocabularies or user-specific partial vocabularies. The selection of the lemmata can be based on corpus evaluations (frequency data), but can also be orientated at the lemma lists of other dictionaries.

According to the dictionary type the lemma selection underlies different criteria: (a) In dictionaries where the subject matter is the general vocabulary you need corpora containing the vocabulary of the standard language (e.g. newspaper texts; to the reasons cf. Schierholz 2001: 97f.), but also the general special field vocabulary from those fields which play an important role in the language community. In addition, corpora containing the oral language use must be examined. (b) For a learner's dictionary it is essential that it contains the basic vocabulary. This can be taken over from old lists but should be confirmed by actual frequency investigations of corpora and the existing word lists of linguistic didactics should also be taken into account. (c) In the selection of neologisms the lexicographer must take into account the sources of a neologism. This can be the regional spread and must be differentiated between occasionalism and neologism. (d) In dialect dictionaries the lemma selection must distinguish between the vocabulary in standard language, regional language and a dialect in the broader sense of the region of the survey. (e) In a variety dictionary on a group specific vocabulary a group external lexicographer has the methodological problem to get enough and reliable material for the selection of the lemma candidates. (f) In specialized dictionaries the lemma selection must be done on the basis of specialized texts and expert knowledge. For example in the WSK volume 1.2 (Wörterbücher zur Sprach- und Kommunikationswissenschaft) with the subject matter syntax (Dürscheid and Schierholz 2013ff.) the lemma selection was processed by (first) scanning, evaluating and comparing the indices and registers from the most important grammars and special field literature (handbooks etc.) to the subject syntax; (second) deciding with an 
expert judgment which of the terms can be graded as dictionary worthy.

This list is not complete and can be extended in detail for every dictionary type and can also be extended for numerous further dictionary types.

\subsubsection{Methods during the phase of material evaluation}

The phase of the material evaluation is a phase where the dictionary articles are drawn up on the basis of the collected and prepared material (cf. Wiegand 1998a: 148ff.). The main task during the making of dictionary articles is the writing of single concrete specifications of different item types.

\section{Methods for the formulation of lexicographical items}

During the dictionary-making the lexicographer applies a philological method when lexicographical items are selected and formulated. The application of methods is based on the knowledge the lexicographer has from experience (theoretical and practical knowledge of lexicography) and on the data which were found out for the purpose of the current step of the lexicographical work. Further, methodological advice which supports the guarantee of a uniform dealing with the items have to be given in the instruction book with item specific orders. In the microstructural programme of a dictionary, which should have been drawn up during the preparation phase, it is determined which items must be written.

For the selection of the example items it must be decided in principle (a) if the text citations should be taken as citation example items in the original form; (b) if non relevant parts of a text citation can be deleted (which is left at the lexicographer's discretion), (c) if an example item should be formed with the help of the lexicographer's competence, (d) if from case to case a combination of the both procedures can be used - for example in the way that original citations should be preferred, but competence example items are permitted if the number of text citations is too small or if no text example is adequate to be used as an example item.

For the syntactical items of verbs - e.g. it is necessary to choose if a facultative complement should be inserted or left out - the lexicographer has to decide this for each concrete article or each version again.

The writing of the items follows certain methods which are partly borrowed from linguistics, especially if linguistic items are concerned. The number of different lexicographical item classes which occur in dictionaries is estimated to be ca. $1000.9^{9}$ The number of methods which is needed during the writing process is smaller because the same method can be applied repeatedly for different items (e.g. to morphology). But this "repeatedly" is not easily and precisely defined and is not described in metalexicography. (a) It can be a method of introspection with a recourse to somebody's own linguistic competence, (b) 
it can be a method of copying from other lexicographical (or not lexicographical) reference works (secondary or tertiary sources such as dictionaries, grammar handbooks), (c) it can be a method of systematic corpus query where variant forms of a lemma are collected in order to decide afterwards depending on the citation situation which item giving the form should be taken into the dictionary.

This decision can be done on the basis of somebody's own competence or with statistical procedures which can be applied to the set of the collected citations. Metalexicographers have to discuss in theory and in methodology which method is the best for a certain dictionary type considering the users and the dictionary functions.

It is clear that it is impossible to have the discussion for each item and it is clear that in concrete cases the decisions must be done with practical orientation. For selected item types it was shown in Lexicographica 30 (2014) how the theoretical preconsiderations and the practical work can be combined with regard to single item types.

\subsubsection{Methods during the preparation of the publication}

In this phase the lexicographer has to do the editorial control (the proofreading) of all written articles (cf. Wiegand 1998a: 149f.), and in an electronic dictionary also the testing of the implemented links, of the multimedia elements etc. and of the whole electronic system (cf. Klosa 2013: 521). To be able to carry this out reliably it would help to have a list of examination methods or a catalogue of proof procedures written down in the instruction book of the dictionary in question.

In addition, the dictionary must be brought into a form which is suitable for the publication, e.g. into a pdf-file where one has to ensure that the result is sufficient for a high quality print.

\subsubsection{Methods of publication}

A dictionary can be published in one medium or in different forms. Since more than 200 years ago, the print version of a dictionary was the one and only relevant publication form. The production of the concrete product was the task of the printing business so that the lexicographer did not have to pay attention to the methods used in the branch of printing.

Nowadays, especially in online lexicography, the lexicographer can do the publication and can organize the processes independently so that the methods which are necessary for successful electronic publishing are in the present more relevant than in the past. This means one has to consider at least the following things:

- The publication can be a closed version dictionary (a static or completed 
dictionary) or a dynamic dictionary or rather, an extension dictionary (cf. Lemberg 2001; Storrer and Freese 1996). (a) In a closed version dictionary all dictionary articles and outer texts must be finished before the dictionary can be published. (b) In an extension dictionary the dictionary articles or parts of the articles which are written can be published, the other articles can follow later step by step. This way of publication has been used in WSK since 2012 when the publisher De Gruyter started with 400 finished articles taken from different WSK-volumes followed by 3000 articles in 2013 and again in 2014. This process will be continued until 2018 and the volume editors (Schierholz and Wiegand 2013ff.) hope that in 2019 the first print version of a WSK volume can be published. (c) If only parts of dictionary articles are published it means that a lemma must not be worked out exhaustively so that frequent and unproblematic readings of a lemma can be written and published first. In this procedure it is also possible to publish at first articles which contain only automatically produced items. The other items can be added later by the lexicographer (cf. Klosa 2013: 522). Whatever opportunity is chosen, different methods will be necessary for this part of the lexicographical work.

- Updated versions can be published in regular or irregular intervals. A regular quarterly revision is published by the online edition of $O E D, 10$ and Duden online ${ }^{11}$ is revised in irregular intervals - which means: every day if necessary. The latter procedure has the advantage that updates can be published immediately so that the users have current access to the newest items in the dictionary and the items can be a recent reflection of reality.

\subsubsection{Methods of data maintenance, reprocessing, post-production}

While in a closed version dictionary maintenance does not play an important role in the concrete lexicographical process, maintenance is relevant if new editions are planned or updates are done regularly or irregularly. In online dictionaries an update is relatively simple and should be foreseen in the work flow. In such cases the following aspects concerning the methods have to be taken into account:

- Which are the update criteria for the regular inspection of the published articles?

- Will the dictionary basis, the based corpus, be updated too? If the answer is "yes", what are the criteria to start with this and when?

- Do the dictionary users have the opportunity to give feedback? What kind of feedback shall it be (direct, indirect or additional feedback cf. Abel and Meyer 2013; Mann 2010: 34, 41)? How will the feedback be integrated in the dictionary update by the lexicographer? 
- Will the storing of the data be done sustainably, e.g. in a format which is not bound to special software?

\subsubsection{The influence of superordinated decisions on used methods}

In section 4.1.1-4.1.7 the mentioned methods were assigned to the respective phases of the lexicographical process. The choice of the methods which can be used also depends on the superordinated facts and decisions which have an effect to the work in all phases. Here the following important aspects can be enumerated: the use of the computer (cf. also Storrer 1996), the dictionary type and the dictionary function.

The use of the computer is nowadays a standard in the lexicographical work; in the dictionary project planning it will be unlikely that a decision between note catalogue and database will be done in favor of the first. But even today, projects exist in which the lexicographer has to work with a handwritten note catalogue, which is the heritage of several generations of lexicographers and in which these notes will be transferred into an electronic database step by step. This was the situation with the Duden publisher 15 to 20 years ago and a little bit later the situation in German academia-projects such as the Grimm dictionary and the Goethe dictionary. But even in dictionary projects where the intensive support of computers is available from the beginning the applied procedures can differ clearly. One reason can be the software used. In dictionary projects with good funding and with an extensive technical know-how of the employees, the software solutions could fit perfectly and could be adapted to project specific needs so that the software can support the methodic procedures very well. In projects with less funding or staff with less training in the technical area one may have to fall back upon simple software products which can support the lexicographical and methodological work in a limited way.

During the entire lexicographical process the dictionary type influences the lexicographical procedures and the used methods. With the help of the needs analysis of a certain dictionary, the determination of the individual respective group of users and - following from that - the planned size of a dictionary, the lexicographer can determine guidelines for text compound structure, for the macrostructure (lemma selection, principles of lexicographical order) and for the microstructure (number and sequence of items) of the dictionary articles. The dictionary type determines the microstructure concerning the elements of the whole set of items. It influences also the composition of the items: e.g. the pronunciation rules in a descriptive pronunciation dictionary are presented differently and more precisely than in a general explanatory dictionary; items giving the meaning in a learner's dictionary will be different from those in specialized dictionary etc. These rules influence the possibilities of the use of many lexicographical methods which are necessary for a successful handling with the data.

Similarly, the dictionary type and partly overlapping with it the dictionary 
functions, influence the lexicographical work and the used methods in all phases. The components of the text compound structure, the lemma selection, the choice and formulation of the items etc. are directed by the dictionary functions (support of text production, text reception, translation and information function) which are orientated to the needs of the envisaged user group. A procedure that is explicitly orientated to dictionary functions must keep an eye on the relevance of the data material in every phase of the lexicographical process. Also the preparation and use of the following results - especially of the lexicographical items - must be done for the support of the dictionary functions. The relevance of all measures should be methodically verified and well-founded.

\subsection{Methods in Dictionary Research}

Metalexicography, as the theory of practical lexicography, has the task of investigating all methods of practical lexicography and their theoretical reflection. This is based on the principle of interest of insights in the area of metalexicography itself, but also to find possibilities of improvement which should influence the lexicographical practice positively. Metalexicography has the task of drawing up a methodology of lexicography and dictionary research altogether in order to deliver a fundamental contribution to the theory of dictionary research. But the study of methods is in some way depending on the theory from which a method comes from. Metalexicography itself has also some specific methods which play no or only an unimportant role in practical lexicography.

In the following section the methods will be considered in connection with the theory elements of the dictionary research as it was worked out by Herbert Ernst Wiegand.

\subsubsection{Systematic dictionary research}

All the methods which can be used for the description and investigation of the dictionary structures belong to the systematic dictionary research. Wiegand (2010) distinguishes between (a) the methods concerning the investigation of the dictionary form and (b) the methods of the presentation. To (a) belong the methods of text segmentation and of structure constructing; to (b) belong the methods of the presentation of the textual structures, the methods of constructing the article structure schemata a well as the methods of the presentation of typologies.

A central metalexicographical text segmentation method is the functionalpositional segmentation (cf. to this and to other text segmentation methods Wiegand 2010: 256ff.). This procedure is applied to dictionary articles to find out the number of items and their types. For each element of a dictionary article (phrases, words, parts of words, abbreviations, punctuation marks, blanks etc. with consideration of the typographical marking up of the elements) it can be 
detected step by step, if a positional determined element has an independent function or if it is part of a larger element which has its own function. With this procedure one can find out which parts of a dictionary article belong together and which tasks are given to these elements by the lexicographer. It is an intersubjective comprehensible method which is applied in dictionary research but it can also be used to explain uncertainty in the dictionary use. This can occur if the lexicographical items in a dictionary article are condensed in a way that an average user who does not know how to apply this method can not decide which interpretation of a lexicographical item is the right one.

The structure constructing methods are built on the text segmentation methods and are used to describe and investigate the structure and hierarchy which exist under the segmented elements. Wiegand's works are based on the concept of the set theory so that the dictionary form is recorded in terms like set, set of carriers, relation, element etc. The reproduction of the construction and the relationship of dictionary components by sets and relations is a method which gives a well-structured presentation of the data which are the constituents of a reference work. Thus many structures can be identified, and the most important ones are the text compound structures, the access structures, the macrostructures, the microstructures, the article constituent structures, the text architectures, the search area structures, the addressing structures, the mediostructures, and the data distribution structures, but there are more. The literature about the single structures is numerous and extensive, a good summary can be found in Engelberg and Lemnitzer (2009: 134ff.), in Wiegand and Fuentes Morán (2010), in the WLWF-1 (2010), and in Gouws, Heid, Schweickard and Wiegand (2013) - the latter one in English. Methods which concern reference structures are worked out in detail in the reference theory (amongst others Wiegand 2011). These procedures were applied in WLWF-1 (2010) and in the WSK so that a successful application in practical lexicography still exists.

Beyond that, even the methods which are used to build up typologies and classifications belong to systematic dictionary research. These procedures are borrowed from other sciences, especially from the philosophy of science. Details of the recent methods in systematic dictionary research can be found particularly in Wiegand (2010); Wiegand and Fuentes Morán (2010); Wiegand, Beer and Gouws (2013: 39ff.).

\subsubsection{Research on Dictionary Use}

In research on dictionary use it shall be investigated in which way a user uses a dictionary, so that the results can help to improve the quality of a dictionary. This affects print and online dictionaries in the same way. ${ }^{12}$ In this research area, methods of empirical social sciences are used, such as observation, written questionnaire, content analysis, test, experiment, protocol on dictionary use or oral comment on dictionary use (cf. Tarp 2009, Lew 2011). Frequently used is the questionnaire in a written form (to advantages and disadvantages cf. e.g. 
Ripfel and Wiegand 1988: 493; Ripfel 1990: 1632; Tono 2001; Lew 2002). The questionnaire can be distributed personally which was the practice in the past and is nowadays used by single persons or by students when they undertake a pilot study during their studies. But in huge projects a questionnaire is organized online, as it was done with the German online dictionary elexiko (cf. Klosa, Koplenig and Töpel 2014). The whole process of planning, realization, evaluation, and critical reflection is described in Koplenig and Müller-Spitzer 2014a: 79ff., Müller-Spitzer 2014c: 85ff., Koplenig and Müller-Spitzer 2014b: 127ff., Müller-Spitzer and Koplenig 2014: 143ff., Koplenig and Müller-Spitzer 2014c: $189 \mathrm{ff}$. The observation of a certain person contains the danger that the personal presence of the researcher influences the act of usage (known as observer's paradox). When choosing the eye-tracking procedure (e.g. Tono 2011; Müller-Spitzer, Michaelis and Koplenig 2014: 209ff.: they call it "Eye-tracking technology") the influence of the researcher is avoided but it must be mentioned that this method allows only to observe the search behavior of the user. ${ }^{13}$ After it, the lexicographer has to interpret the eye movements of the test subject and the definite intention the user/subject had cannot be interpreted unambiguously. Besides this, the expenditure of the performance of only a single experiment is enormous (cf. Runte 2015 and briefly also Kemmer 2014: 275).

A specific lexicographical method is the protocol on dictionary usage (cf. Ripfel and Wiegand 1988: 494f.; Wiegand 1998a: 974ff.), in which the described procedures can be combined. With the help of a protocol it can be shown in which way a subject uses a dictionary, which acts of usage are successful and which problems arise during the dictionary use in a certain dictionary to certain questions and search actions. The protocol process of the single working steps can be done (a) if the subject gets tasks which make the use of a dictionary necessary (cf. Wiegand 1985); (b) if the subject writes a content analysis, where they document the act of usage. On the one hand, this method requires a certain ability of the test subject, on the other hand it is not unproblematic to make the evaluation objectively; (c) if a think-aloud-protocol is made, by articulating during the usage, which action is carried out, why this action is carried out, which unexpected complications occur and how the problems were approached (method of loud thinking). The utterances of the test subject are recorded and analyzed (cf. amongst others Wiegand 1998a: 1010ff.; Hartmann 2001: 118f.).

These procedures can show ways of improving a dictionary, but additionally they give the chance to formulate a hypothesis, which can be the starting point of systematically gathering information (e.g. in experiments or tests).

Online dictionaries can also be investigated by the evaluation of the log files which contain automatically produced protocol data to record the activities of the users. ${ }^{14}$ This method can give a relatively good overview of how often and at what time which expressions were looked up, and the log files can also give information about which expressions were never looked up in a reference work. It reveals how users go about using the online dictionary, e.g. which 
search expression is entered into the search field. So the lexicographer has the possibility to react to this (cf. for example Rautmann 2014 for Duden online). But one has to be careful with the interpretation of the data because the following considerations should be included, for instance: (a) Does a long break between user activities mean that the user needed much time to read the dictionary article? (b) Was the user interrupted by other things, e.g. coffee break? Having (a) it can mean that the article should be designed more comprehensible and more clearly structured, having (b) it means nothing regarding the dictionary. (c) Does the looking up of words from vulgar and sexual vocabulary in a high frequency mean (cf. Docherty 2000: 73; De Schryver and Joffe 2004: 190; Bergenholtz and Johnsen 2005: 126) that this vocabulary part needs special explanation and clarification? (d) Is this kind of search part of reading dictionaries for entertainment or to kill time (which is called "lexicotainment"; cf. Bergenholtz 2011: 16)? It is relatively unlikely to give a reliable interpretation of this situation of usage because beneath the log file data no contact with the dictionary users exists.

\subsubsection{Historical Dictionary Research}

This section deals with all lexicographical processes in a historical context and pursues the goal to write the history of lexicography and to develop a theory of the history of lexicography (cf. Wiegand 1998a: 10). In this process the conditions of culture and society in different ages and time epochs are involved because they had a major influence on lexicographical activities. Very often it can only be adequately judged retrospectively in which way lexicographical processes were influenced by the social situation. So the methods which are used in sciences of history are important for the historical dictionary research. Beyond that, the construction of typologies of historical dictionaries (cf. Reichmann 2012: 91ff.) and the research on dictionary use in the past play a dominant role.

In the area of practical lexicography all the methods which play a role in the making of historical dictionaries must be taken into consideration. ${ }^{15}$ These methods include the use of text corpora, the special conditions in using historical corpora, specific procedures of the lemma selection, the peculiarities of writing and - following from that - the problems with the macrostructure of the lemmata, the special conditions of citation excerption, as well as the characteristics in historical morphology and word formation. During this work, procedures of historical linguistics should be used but also the methods of grapholinguistics and of investigation of language change. Also the mentioned methods of the systematic dictionary research will be used in historical practical lexicography.

The procedures to find out the meaning of words and how to express the paraphrase of meaning are described precisely and extensively by Reichmann (2012: 218ff.) as are historical excerpts which underlie different principles because of a completely different empirical basis than the data basis which is at hand 
for the contemporary languages. (Reichmann 2012: 124ff., 472ff.).

\subsubsection{Critical Dictionary Research}

Critical dictionary research has as the subject matter the entire amount of scientific and non scientific texts which exist in the area of lexicography and dictionary research, as well as all dictionaries because in many cases these are the subject of that entire amount of texts. 16

This means that the critical dictionary research in a wider sense comprises the texts from every research area (sensu Wiegand 1998a), i.e. works on research of dictionary use, on the production of a dictionary, on the historical dictionary research, on the systematic dictionary research, and texts concerning the total of all dictionaries.

Critical dictionary research in a narrower sense concentrates primarily on the analysis of dictionaries themselves with regard to all properties a dictionary has. This can be done in evaluations of single items or of the entire dictionary and it will be published in dictionary criticisms, monographies, essays or in reviews.

The outcome of this is that in the framework of critical dictionary research, in a wider sense, all methods which occur in the single research areas of lexicography and dictionary research, belong to the subject matter. Even for critical research on dictionaries in a narrower sense, many methods from the mentioned research areas of dictionary research play an important role. The following can be included:

(a) The text segmentation methods and structure constructing methods (section 4.2.1), which are used by dictionary critics in order to find out the existing structures in an available dictionary. These structures can be analyzed and criticized relating to the appropriateness of the dictionary type, dictionary functions, groups of users etc.

(b) Knowledge about the methods of research on dictionary use (section 4.2.2) is relevant because a dictionary researcher must take notice of the research results on dictionary use in a critical way. This is the basis in order to formulate fundamental statements on the benefit of a dictionary for the envisaged users. Besides, investigations on dictionary use which aim to improve existing dictionaries can themselves be counted as critical or self-critical measurements and can also be counted to the critical dictionary research.

(c) Knowledge of methods and insights of historical dictionary research (section 4.2.3) are necessary to categorize the historical dictionaries in case of critics or of a comparison with other contemporary dictionaries in a reliable way.

(d) Philological (qualitative) methods are necessary for the analysis with regard to contents of dictionary texts, e.g. to find out actual or, in cul- 
tural retrospective, trendy and ideological influences in meaning paraphrases, outer texts etc. (cf. Haß-Zumkehr 2000 on lexicographical methodics in national socialism).

(e) Quantitative analysis and statistical methods are necessary, for instance, if one wants to give a reasonable estimation of the number of the items in a dictionary. This includes methods on a projection of the lemma number because it is impossible to read the whole dictionary or to count all lemmata. Instead of this a sample should be taken from the dictionary, which takes into consideration the whole word list from A to $\mathrm{Z}$ equally. The process to do this in a reliable way is worked out among others in Wiegand (1990: 2127) and in Mann (2013: 745ff.).

(f) Another method is to count a certain lemma stretch (e.g. the stretch I) and to extrapolate by the well-known relations of the individual lemma stretches to each other how many lemmata the entire dictionary contains. On the basis of the results, a judgment about the macrostructural coverage of the vocabulary of the dictionary can be given. This can be set in relation to the population of a language, a variety or a corpus.

If a certain item type shall be checked critically, similar prerequisites and difficulties as for the lemma counting exist concerning the sample. It is not possible to make a meaningful analysis about a dictionary by reading or examining a few pages of the dictionary in an unsystematic way and extrapolating to the properties in the complete work. It is not possible to take the first 10 or 20 pages of a dictionary as a basis for an overall assessment of this dictionary. A possible and systematical evaluation method is for instance to start on the second page of the word list, to take from that page the first dictionary article into the sample and to repeat this procedure on every 20th page. By doing this, one collects data systematically to create a sample that is equally distributed over the entire word list. Afterwards this procedure should be repeated starting with the 12th page. Through this you will get two samples of the same size so that all analyses which will be done can be compared and can be checked with regard to their reliability. This method was chosen by Schierholz $(1998 ; 2002)$ when morphological items in two learner's dictionaries of German were analyzed and compared with the data of text corpora of standard German.

The dictionary evaluation is an essential part of the critical dictionary research. ${ }^{17}$ In principle, different text types must be distinguished (cf. also Engelberg and Lemnitzer 2009: 186ff.), which can be used to write such an evaluation: (a) the expert discussion (in conferences, in education, in panels etc.); (b) the dictionary review in a journal or in the press; (c) the online discussion in a newsgroup; (d) the systematic and comparing inspection of detailed questions; (e) the critical and constructive investigation of an entire dictionary carried out from different perspectives and with different formulations of a question. This was successfully performed in the area of learner's lexicography 
for the German dictionaries of Langenscheidt (LGwDaF) and De Gruyter $(\mathrm{dGwDaF})$ in the collection of essays on pedagogical lexicography by Wiegand (1998b; 2002b). In the contributions the correctness, the reliability, the completeness of lexicographical items, the appropriateness of the lemma selection, the textual structures of the dictionary articles and of the dictionary, the text compound structure, the reference practice, as well as the user friendliness were analyzed. Because in a learner's dictionary the group of users is defined very clearly it is easy to check if the intended functions were fulfilled and to make pedagogically motivated suggestions for the improvement of a new dictionary edition.

In the framework of an evaluation in any case the viewpoint of the researcher must be reflected critically because it there is a difference between a dictionary being evaluated from the perspective of an expert or from the perspective of a user who is the intended target of a dictionary. This can be demonstrated by two examples: (a) Many users of the Langenscheidt dictionaries think positively about the coloured typeface used for the lemma sign, but many metalexicographers do not agree on this. ${ }^{18}$ (b) No metalexicographer has a problem identifying in the dictionary article to "singen" (cf. Fig. 1) the abbreviation "e-e" which was used in the first editions of $\operatorname{LGwDaF}(1994,2003)$. The abbreviation "e-e" is "eine", but foreign-language students and also German students asked more than one time in seminars what the "e-e" would mean.

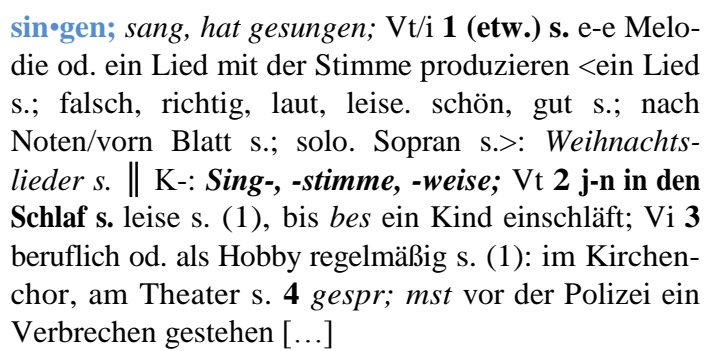

Figure 1: Dictionary article for the lemma "singen" in LGwDaF (2003).

To check these questions, corpus investigations, analysis of the literature and reference works, especially dictionaries, must be done. When assessing dictionaries the critical interpretation of the data is always placed at the end. This is in any case a philological method which is based on the individual subjective judgment ability.

\section{Conclusion}

This overview should have made clear that methods must be used regularly in lexicographical practice and in theory if recent and reliable dictionaries shall be produced, analyzed or improved. For this, the scientific, economic, technologi- 
cal, structural and especially thematic aspects have to be considered.

The overview does not claim completeness referring to the number of methods or the description of methods or the publications on methods. ${ }^{19}$ But it should be the starting point for further investigation into methods and methodology in lexicography and dictionary research because the reliable application of a reliable method will support the advancement of our activities in future.

\section{6. $\quad$ Notes}

1. Critical aspects to the Function Theory are found amongst others in Bogaards (2010), Rundell (2012: 63), and Swanepoel (2015). A general application to lexicography of language for special purposes can be found in Mihindou (2013: 112ff.).

2. Schaeder 1981: 29. In German: "[...] als einzelne wissenschaftliche Verfahren bezeichnet werden, die dazu dienen, gesicherte und nachprüfbare Erkenntnisse über wissenschaftliche Objekte bzw. Gegenstände zu gewinnen".

3. Original in German: "Eine Methode ist eine geordnete Menge von Handlungsanweisungen, deren Befolgung in mindestens einer geordneten Reihenfolge und unter Beachtung aller methodenzugehöriger Korrektheitsbedingungen erfolgen muss, damit das gewünschte Ergebnis erhältlich ist."

4. To the utilization of corpora in lexicography cf. Gouws, Heid, Schweickard and Wiegand 2013: 1336ff.

5. Wiegand 1984: 559: "Bei der lexikographischen Tätigkeit wird, und zwar determiniert durch den jeweiligen Typ des zu erarbeitenden Nachschlagewerkes, auf Ergebnisse, Methoden und Theorien aus verschiedenen Wissenschaften zurückgegriffen." Cf. also Wiegand 1998a, 100.

6. The method dictionaries from dictionaries ("Wörterbücher-aus-Wörterbüchern-Methode") is shown by Wiegand (1998b: 649) within dictionaries from the 16th century. Meyer and Gurevych (2014) demonstrate that in 2013 even the sources of Wiktionary which is a collaborative produced dictionary can be found in other dictionaries.

7. The allocation of the phases follows basically Wiegand (1998a), which is adopted by Engelberg and Lemnitzer (2009), Klosa (2013) and can be found in the WLWF-I (201: 8-21).

8. This term is a synonym to "manual" or "textbook on dictionary making" (cf. Hartmann 2013: 600) and it is a translation of the German term "Instruktionsbuch" which Schierholz and Wiegand use in their conception of the WSK project (Schierholz and Wiegand 2004: 205ff.)

9. Wiegand (2005: 344ff.) enumerates more than 1.500 item classes, including many synonyms.

10. Cf. http://public.oed.com/the-oed-today/recent-updates-to-the-oed/ [2015-06-21].

11. Cf. http://www.duden.de/woerterbuch [2015-06-21].

12. Cf. the critical perspective on user research in Bergenholtz and Bergenholtz 2011.

13. Kemmer (2014) who investigates the reception of illustrations and the items giving the meaning in online dictionaries combines the user questionnaire and the eye-tracking method.

14. Cf. Bergenholtz and Johnson (2013). Another useful application of log file data, not concerning the research on dictionary use, is shown by Koplenig, Meyer and Müller-Spitzer (2014).

15. Methods used in different languages can be found in Gouws et al. 2013: 612ff.

16. Cf. Ripfel (1989).

17. Cf. Kemmer (2010); Swanepoel (2008; 2013). 
18. The normal users mentioned here were students in different seminars hold at the FriedrichAlexander University of Erlangen-Nürnberg, the metalexicographers are colleagues who mentioned this in special field conversation in some informal situations.

19. Cf. the selected bibliography in Mann and Schierholz 2014: 33-57. The bibliography of this article contains supplements especially of publications in English.

\section{Bibliography}

Abel, Andrea and Christian M. Meyer. 2013. The Dynamics outside the Paper: User Contributions to Online Dictionaries. Kosem, Iztok et al. 2013. Electronic Lexicography in the 21st Century: Thinking Outside the Paper. Proceedings of the eLex 2013 Conference, 17-19 October 2013, Tallinn, Estonia: 179-194. Ljubljana/Tallinn: Trojina, Institute for Applied Slovene Studies/Eesti Keele Instituut. Online: http://eki.ee/elex2013/proceedings/eLex2013_13_Abel+Meyer.pdf [2015-0621].

Albert, Ruth and Cor J. Koster. 2002. Empirie in Linguistik und Sprachlehrforschung. Ein methodologisches Arbeitsbuch. Tübingen: Gunther Narr.

Albert, Ruth and Nicole Marx. 2010. Empirisches Arbeiten in Linguistik und Sprachlehrforschung. Anleitung zu quantitativen Studien von der Planungsphase bis zum Forschungsbericht. Tübingen: Gunther Narr.

Beltrami, Pietro G. 2013. Theory of Dictionary Management. Gouws, Rufus H., Ulrich Heid, Wolfgang Schweickard and Herbert Ernst Wiegand (Eds.). 2013: 524-530.

Bergenholtz, Henning. 1989. Probleme der Selektion im allgemeinen einsprachigen Wörterbuch. Hausmann, Franz Josef, Oskar Reichmann, Herbert Ernst Wiegand and Ladislav Zgusta (Eds.). 1989: 772-779.

Bergenholtz, Henning. 1995. Lemma Selection. Bergenholtz, Henning and Sven Tarp (Eds.). 1995. Manual of Specialised Lexicography. The Preparation of Specialised Dictionaries: 98-104. Amsterdam/Philadelphia: John Benjamins.

Bergenholtz, Henning. 2011. Access to and Presentation of Needs-adapted Data in Monofuntional Internet Dictionaries. Fuertes-Olivera, Pedro A. and Henning Bergenholtz (Eds.). 2011: 30-53.

Bergenholtz, Henning and Inger Bergenholtz. 2011. A Dictionary is a Tool, a Good Dictionary is a Monofunctional Tool. Fuertes-Olivera, Pedro A. and Henning Bergenholtz (Eds.). 2011: 187-207.

Bergenholtz, Henning and Mia Johnsen. 2005. Log Files as a Tool for Improving Internet Dictionaries. Hermes. Journal of Linguistics 34: 117-141.

Bergenholtz, Henning and Mia Johnsen. 2013. User Research in the Field of Electronic Dictionaries: Methods, First Results, Proposals. Gouws, Rufus H., Ulrich Heid, Wolfgang Schweickard and Herbert Ernst Wiegand (Eds.). 2013: 556-568.

Bergenholtz, Henning and Gregor Meder. 1998. Die äußere Selektion in Langenscheidts Großwörterbuch Deutsch als Fremdsprache. Wiegand, Herbert Ernst (Ed.). 1998b: 285-296.

Bergenholtz, Henning and Joachim Mugdan. 1990. Formen und Probleme der Datenerhebung II: Gegenwartsbezogene synchronische Wörterbücher. Hausmann, Franz Josef, Oskar Reichmann, Herbert E. Wiegand and Ladislav Zgusta (Eds.). 1990: 1611-1625.

Bergenholtz, Henning and Sven Tarp. 2002. Die moderne lexikographische Funktionslehre. Diskussionsbeitrag zu neuen und alten Paradigmen, die Wörterbücher als Gebrauchsgegenstände verstehen. Lexicographica. International Annual for Lexicography 18: 253-263. 
Bielińska, Monika. 2014. Methoden der Übersetzungswissenschaft und der zweisprachigen Lexikographie. Lexicographica 30: 213-246.

Bocorny Finatto, Maria José. 2014. New Methods for Specialized Lexicography: Brazilian Approach Examples. Lexicographica 30: 247-261.

Bogaards, Paul. 2010. Lexicography: Science without Theory? De Schryver, Gilles-Maurice (Ed.). 2010. A Way with Words: Recent Advances in Lexical Theory and Analysis. A Festschrift for Patrick Hanks: 313-322. Kampala: Menha Publishers.

Bortz, Jürgen and Nicola Döring. 2006. Forschungsmethoden und Evaluation für Human- und Sozialwissenschaftler. 4th revised edition. With 156 Figures and 87 Tables. Heidelberg: Springer.

Burch, Thomas, Ruth Christmann, Vera Hildenbrandt and Thomas Schares. 2000. Ein "Hausbuch" für alle? - Das Deutsche Wörterbuch von Jacob und Wilhelm Grimm auf CD-ROM und im Internet. Braungart, Georg, Karl Eibl and Fotis Jannidis (Eds.). 2000. Jahrbuch für Computerphilologie 2: 11-34. Paderborn: mentis. Also online: http://computerphilologie.digitalhumanities.de/jg00/christma/christma.html [2014-04-08].

Deppermann, Arnulf. 2008. Gespräche analysieren. Eine Einführung in konversationsanalytische Methoden. Qualitative Sozialforschung 3. 4. Aufl. Wiesbaden: VS Verlag für Sozialwissenschaften.

De Schryver, Gilles-Maurice and David Joffe. 2004. On How Electronic Dictionaries are Really Used. Williams, Geoffrey and Sandra Vessier (Eds.). 2004. Proceedings of the Eleventh EURALEX International Congress, EURALEX 2004, Lorient, France, July 6-10, 2004: 187-196. Lorient: Faculté des Lettres et des Sciences Humaines, Université de Bretagne Sud. Also online: http://tshwanedje.com/publications/euralex2004-LOGS.pdf [2014-04-10].

dGWDaF (2000) = Kempcke, Günter (Ed.). 2000. De Gruyter Wörterbuch Deutsch als Fremdsprache. Berlin/New York: Walter de Gruyter.

Diekmann, Andreas. 2007. Empirische Sozialforschung: Grundlagen, Methoden, Anwendungen. Vollständig überarb. und erw. Neuausgabe 2007, 7. Aufl., (24. Aufl. der Gesamtausgabe). Reinbek bei Hamburg 2013.

Dornseiff, Franz. 2004. Der deutsche Wortschatz nach Sachgruppen. 8., völlig neu bearb. und mit einem vollständigen alphabetischen Zugriffsregister versehene Auflage von Uwe Quasthoff. Mit einer lexikographisch-historischen Einleitung und einer ausgewählten Bibliographie zur Lexikographie und Onomasiologie von Herbert Ernst Wiegand. Berlin/New York: Walter de Gruyter.

Drosdowski, Günther. 1977. Nachdenken über Wörterbücher: Theorie und Praxis. Drosdowski, Günther, Helmut Henne and Herbert E. Wiegand (Eds.). 1977. Nachdenken über Wörterbücher: 103-143. Mannheim/Wien/Zürich: Bibliographisches Institut, Dudenverlag.

Dürscheid, Christa and Stefan J. Schierholz (Eds.). 2013ff. Grammatik. Ein Konsultationswörterbuch mit englischen Übersetzungen (WSK-Online-Version). Berlin/New York: De Gruyter. [http://www. degruyter.com/view/db/wsk] [2015-06-21].

Engelberg, Stefan and Lothar Lemnitzer. 2009. Lexikographie und Wörterbuchbenutzung. 4., überarb. und erw. Aufl. Tübingen: Stauffenburg.

Evert, Stefan. 2005. The Statistics of Word Cooccurrences. Word Pairs and Collocations. Dissertation. Stuttgart: Institut für maschinelle Sprachverarbeitung, University of Stuttgart. Also online: http://elib.uni-stuttgart.de/opus/volltexte/2005/2371/ [2014-04-08].

Fuertes-Olivera, Pedro A. and Henning Bergenholtz (Eds.). 2011. e-Lexicography. The Internet, Digital Initiatives and Lexicography. London/New York: Continuum.

Geyken, Alexander. 2014. Methoden bei der Wörterbuchplanung in Zeiten der Internetlexikographie. Lexicographica 30: 77-111. 
Gouws, Rufus H., Ulrich Heid, Wolfgang Schweickard and Herbert Ernst Wiegand (Eds.). 2013. Dictionaries. An International Encyclopedia of Lexicography. Supplementary Volume: Recent Developments with Focus on Electronic and Computational Lexicography. Handbücher zur Sprach- und Kommunikationswissenschaft 5.4. Berlin/Boston: Mouton de Gruyter.

Gouws, Rufus H. and Daniël J. Prinsloo. 2005. Principles and Practice of South African Lexicography. Stellenbosch: SUN PReSS.

Hartmann, Reinhard Rudolf Karl. 2001. Teaching and Researching Lexicography. Applied Linguistics in Action Series. Harlow: Longman/Essex: Pearson Education.

Hartmann, Reinhard R.K. 2013. Aids in Metalexicographic Research. Gouws, Rufus H., Ulrich Heid, Wolfgang Schweickard and Herbert Ernst Wiegand (Eds.). 2013: 596-611.

Hauser, Ralf and Angelika Storrer. 1996. Probleme und Lösungen beim Parsen von Wörterbüchern. Feldweg, Helmut and Erhard W. Hinrichs (Eds). 1996. Lexikon und Text. Wiederverwendbare Methoden und Ressourcen zur linguistischen Erschließung des Deutschen. Lexicographica. Series Maior 73: 53-67. Tübingen: Niemeyer.

Hausmann, Franz Josef, Oskar Reichmann, Herbert E. Wiegand and Ladislav Zgusta (Eds.). 1989. Wörterbücher. Ein internationales Handbuch zur Lexikographie/Dictionaries. An International Encyclopedia of Lexicography/Dictionnaires. Encyclopédie internationale de lexicographie. Handbücher zur Sprach- und Kommunikationswissenschaft 5.1. Berlin/New York: Walter de Gruyter.

Hausmann, Franz Josef, Oskar Reichmann, Herbert E. Wiegand and Ladislav Zgusta (Eds.). 1990. Wörterbücher. Ein internationales Handbuch zur Lexikographie/Dictionaries. An International Encyclopedia of Lexicography/Dictionnaires. Encyclopédie internationale de lexicographie. Handbücher zur Sprach- und Kommunikationswissenschaft 5.2. Berlin/New York: Walter de Gruyter.

Heid, Ulrich. 2008. Corpus Linguistics and Lexicography. Lüdeling, Anke and Merja Kytö (Eds.). 2008. Corpus Linguistics. An International Handbook. Vol. 1. Handbücher zur Sprach- und Kommunikationswissenschaft 29.1: 131-153. Berlin/New York: Walter de Gruyter.

Hirschfeld, Ursula and Eberhard Stock. 2014. Wie kommt die Aussprache ins (Aussprache-) Wörterbuch? Methoden, Probleme und Ergebnisse normphonetischer Untersuchungen zur deutschen Standardaussprache. Lexicographica 30: 262-290.

Kemmer, Katharina. 2010. Onlinewörterbücher in der Wörterbuchkritik. Ein Evaluationsraster mit 39 Beurteilungskriterien. Online publizierte Arbeiten zur Linguistik 2: 1-33.

Kemmer, Katharina. 2014. Rezeption der Illustration, jedoch Vernachlässigung der Paraphrase? Müller-Spitzer, Carolin (Ed.). 2014a: 251-278.

Klosa, Annette. 2013. The Lexicographical Process (with Special Focus on Online Dictionaries). Gouws, Rufus H., Ulrich Heid, Wolfgang Schweickard and Herbert Ernst Wiegand (Eds.). 2013: 517-524.

Klosa, Annette, Alexander Koplenig and Antje Töpel. 2014. Benutzerwünsche und -meinungen zu dem monolingualen deutschen Onlinewörterbuch elexiko. Müller-Spitzer, Carolin (Ed.). 2014a: 281-384.

Koplenig, Alexander. 2014. Empirical Research into Dictionary Use. Müller-Spitzer, Carolin (Ed.). 2014a: 55-76.

Koplenig, Alexander, Peter Meyer and Carolin Müller-Spitzer. 2014. Dictionary Users Do Look Up Frequent Words. A Log File Analysis. Müller-Spitzer, Carolin (Ed.). 2014a: 229-249.

Koplenig, Alexander and Carolin Müller-Spitzer. 2014a. The First Two International Studies on Online Dictionaries — Background Information. Müller-Spitzer, Carolin (Ed.). 2014a: 79-84. 
Koplenig, Alexander and Carolin Müller-Spitzer. 2014b. General Issues of Online Dictionary Use. Müller-Spitzer, Carolin (Ed.). 2014a: 127-141.

Koplenig, Alexander and Carolin Müller-Spitzer. 2014c. Question of Design. Müller-Spitzer, Carolin (Ed.). 2014a: 189-204.

Landau, Sidney I. 1989. Dictionaries. The Art and Craft of Lexicography. Cambridge: Cambridge University Press. [First print New York: Scribner, 1984.]

Lemnitzer, Lothar and Heike Zinsmeister. 2006. Korpuslinguistik. Eine Einführung. Tübingen: Narr.

Lew, Robert. 2002. Questionnaires in Dictionary Use Research: A Reexamination. Braasch, Anna and Claus Povlsen (Eds.). 2002. Proceedings of the Tenth EURALEX International Congress, EURALEX 2002, Copenhagen, Denmark, August 13-17, 2002. Volume 1: 267-271. Copenhagen: Center for Sprogteknologi, University of Copenhagen.

Lew, Robert. 2011. User Studies: Opportunities and Limitations. In: Akasu, Kaoru and Satoru Uchida (Eds.). 2011. ASIALEX 2011 Proceedings. LEXICOGRAPHY: Theoretical and Practical Perspectives. Papers Submitted to the Seventh ASIALEX Biennial International Conference. Kyoto Terrsa, Kyoto, Japan, August 22-24, 2011: 7-16. Kyoto: Asian Association for Lexicography.

LGwDaF (1994) = Götz, Dieter, Günther Haensch and Hans Wellmann (Eds.). 1994. Langenscheidts Großwörterbuch Deutsch als Fremdsprache. Das neue einsprachige Wörterbuch für Deutschlernende. Third Edition. Berlin/Munich: Langenscheidt.

LGwDaF (2003) = Götz, Dieter, Günther Haensch and Hans Wellmann (Eds.). 2003. Langenscheidts Großwörterbuch Deutsch als Fremdsprache. Revised edition. Berlin [etc.]: Langenscheidt.

Mann, Michael. 2010. Internet-Wörterbücher am Ende der "Nullerjahre": Der Stand der Dinge. Eine vergleichende Untersuchung beliebter Angebote hinsichtlich formaler Kriterien unter besonderer Berücksichtigung der Fachlexikographie. Lexicographica 26: 19-45.

Mann, Michael. 2013. German II: Synchronic Lexicography. Gouws, Rufus H., Ulrich Heid, Wolfgang Schweickard and Herbert Ernst Wiegand (Eds.). 2013: 742-816.

Mann, Michael and Stefan J. Schierholz. 2014. Methoden in der Lexikographie und Wörterbuchforschung. Ein Überblick mit einer Auswahlbibliographie. Lexicographica 30: 3-57.

Meindl, Claudia. 2011. Methodik für Linguisten. Eine Einführung in Statistik und Versuchsplanung. Tübingen: Narr.

Meyer, Christian M. and Iryna Gurevych. 2014. Methoden bei kollaborativen Wörterbüchern [Methods in Collaborative Dictionaries/Méthodes dans le domaine des dictionnaires collaboratifs]. Lexicographica 30: 187-212.

Mihindou, Guy-Roger. 2013. LSP Lexicography in the Academic Discourse. Botha, Willem, Paul Mavoungou and Dion Nkomo (Eds.). 2013. Festschrift Rufus H. Gouws: 111-126. Stellenbosch: SUN PReSS.

Müller-Spitzer, Carolin (Ed.). 2014a. Using Online Dictionaries. Lexicographica. Series Maior 145. Berlin/Boston: De Gruyter.

Müller-Spitzer, Carolin. 2014b. Methoden der Wörterbuchbenutzungsforschung. Lexicographica 30: $112-151$.

Müller-Spitzer, Carolin. 2014c. Empirical Data on Contexts of Dictionary Use. Müller-Spitzer, Carolin (Ed.). 2014a: 85-126.

Müller-Spitzer, Carolin and Alexander Koplenig. 2014. Online Dictionaries: Expectations and Demands. Müller-Spitzer, Carolin (Ed.). 2014a: 143-188.

Müller-Spitzer, Carolin, Frank Michaelis and Alexander Koplenig. 2014. Evaluation of a New Web Design For the Dictionary Portal OWID. Müller-Spitzer, Carolin (Ed.). 2014a. 207-228. 
Piotrowski, Michael. 2012. Natural Language Processing for Historical Texts. Synthesis Lectures on Human Language Technologies 17. San Rafael, CA: Morgan \& Claypool.

Quasthoff, Uwe. 2004. Methodologische Einführung. Dornseiff, Franz. 2004: 193*-206*.

Rautmann, Karin. 2014. Duden online und seine Nutzer. Abel, Andrea and Annette Klosa (Eds.). 2014. Der Nutzerbeitrag im Wörterbuchprozess. 3. Arbeitsbericht des wissenschaftlichen Netzwerks "Internetlexikografie": 49-62. Mannheim: Institut für Deutsche Sprache. (OPAL — Online publizierte Arbeiten zur Linguistik 4/2014), Online: http://pub.ids-mannheim.de/laufend/opal/ opal14-4.html [2014-05-28].

Reichmann, Oskar. 1990. Formen und Probleme der Datenerhebung I: Synchronische und diachronische historische Wörterbücher. Hausmann, Franz Josef, Oskar Reichmann, Herbert Ernst Wiegand and Ladislav Zgusta (Eds.). 1990: 1588-1611.

Reichmann, Oskar. 2012. Historische Lexikographie. Ideen, Verwirklichungen, Reflexionen an Beispielen des Deutschen, Niederländischen und Englischen. Studia Linguistica Germanica 111. Berlin/Boston: Walter de Gruyter.

Ripfel, Martha. 1989. Wörterbuchkritik. Eine empirische Analyse von Wörterbuchrezensionen. Lexicographica Series Maior 29. Tübingen: Max Niemeyer.

Ripfel, Martha. 1990. Probleme der Erhebung metalexikographischer Daten. Hausmann, Franz Josef, Oskar Reichmann, Herbert E. Wiegand and Ladislav Zgusta (Eds.). 1990: 1631-1638.

Ripfel, Martha and Herbert Ernst Wiegand. 1988. Empirische Wörterbuchbenutzungsforschung. Wiegand, Herbert Ernst (Ed.): 1986. Studien zur neuhochdeutschen Lexikographie VI. Volume 2. Germanistische Linguistik 87-90: 491-520. Hildesheim/New York/Zürich: Georg Olms.

Romary, Laurent and Andreas Witt. 2014. Méthodes pour la représentation informatisée de données lexicales/Methoden der Speicherung lexikalischer Daten. Lexicographica 30: 152-186.

Rundell, Michael. 2012. It Works in Practice but Will it Work in Theory? The Uneasy Relationship between Lexicography and Matters Theoretical. Fjeld, R.V. and J.M. Torjusen (Eds.). 2012. Proceedings of the 15th Euralex International Congress, 7-11 August 2012, Oslo: 47-92. Oslo: Department of Linguistics and Scandinavian Studies, University of Oslo.

Runte, Maren. 2015. Lernerlexikographie und Wortschatzerwerb. Lexicographica. Series Maior 150. Berlin/Boston: De Gruyter.

Schaeder, Burkhard. 1981. Lexikographie als Praxis und Theorie. Reihe Germanistische Linguistik 34. Tübingen: Niemeyer.

Schierholz, Stefan J. 1998. Die Grammatik der Substantive in Langenscheidts Großwörterbuch Deutsch als Fremdsprache. Wiegand, Herbert Ernst (Ed.). 1998. Perspektiven der pädagogischen Lexikographie des Deutschen. Untersuchungen anhand von Langenscheidts Großwörterbuch Deutsch als Fremdsprache. Lexicographica. Series Maior 86: 88-103.Tübingen: Max Niemeyer.

Schierholz, Stefan J. 2001. Präpositionalattribute. Syntaktische und semantische Analysen. Linguistische Arbeiten 447. Tübingen: Max Niemeyer.

Schierholz, Stefan J. 2002. Die Grammatik der Substantive im de Gruyter Wörterbuch Deutsch als Fremdsprache. Wiegand, Herbert Ernst (Ed.). 2002b: 75-90.

Schierholz, Stefan J. 2008a. Einige grundlegende Überlegungen zur Corpuslinguistik. Lenz, Friedrich and Stefan J. Schierholz (Eds.). 2008. Corpuslinguistik in Lexik und Grammatik: 1-14. 2. Aufl. Tübingen: Stauffenburg.

Schierholz, Stefan J. 2008b. Corpusbasierte Operationalisierungsstrategien zur Bestimmung von Valenzpartnern. Valentin, Jean-Marie (Ed.). 2008. Akten des XI. Internationalen Germanistenkongres- 
ses Paris 2005 "Germanistik im Konflikt der Kulturen": 37-48. Bern: Peter Lang. (Jahrbuch für Internationale Germanistik. Series A: Kongressberichte. Bd. 80/4. Empirische Grundlagen moderner Grammatikforschung - Integrative Zugriffe auf Phänomene des Sprachwandels - Lexik und Lexikologie: sprachpolitische Einstellungen und Konflikte - Sprache und Diskurs in den neuen Medien).

Schierholz, Stefan J. 2013. Welches Corpus für welche Untersuchung? Grucza, Franciszek et al. (Eds.). 2013. Akten des XII. Internationalen Germanistenkongresses Warschau 2010: 313-321. Jahrbuch für Internationale Germanistik. Series A: Kongressberichte. Bern: Peter Lang.

Schierholz, Stefan J. and Herbert Ernst Wiegand. 2004. Die Wörterbücher zur Sprach- und Kommunikationswissenschaft (WSK). Eine neue Konzeption der linguistischen Fachlexikographie und ihre computergestützte Praxis. Lexicographica 20. 2004 [2005]: 164-264.

Schierholz, Stefan J. and Herbert Ernst Wiegand (Eds.). 2013ff. Wörterbücher zur Sprach- und Kommunikationswissenschaft/Dictionaries of Linguistics and Communication Science. Online-Version. Berlin/New York: De Gruyter. [http://www.degruyter.com/view/db/wsk] [2015-06-21].

Schierholz, Stefan J. and Eric Windisch. 1991. Der Duden unter der Lupe. Quantitative Analysen zur Makrostruktur des Duden-Universalwörterbuchs. Lexicographica 7: 125-168.

Schlobinski, Peter. 1996. Empirische Sprachwissenschaft. Wiesbaden: Westdeutscher Verlag.

Scholze-Stubenrecht, Werner. 2002. "Die Auswahl der Einträge ist äußerst beliebig". Warum Jagdherr und Pokémon nicht im Duden stehen. Sprachwissenschaft 27: 225-248.

Storrer, Angelika. 1996. Metalexikographische Methoden in der Computerlexikographie. Wiegand, Herbert Ernst (Ed.). 1996. Wörterbücher in der Diskussion II. Lexicographica. Series Maior 70: 239-255. Tübingen: Max Niemeyer.

Storrer, Angelika and Katrin Freese. 1996. Wörterbücher im Internet. Deutsche Sprache 24(2): 97153.

Svensén, Bo. 1993. Practical Lexicography. Principles and Methods of Dictionary-Making. Oxford/New York: Oxford University Press.

Swanepoel, Piet. 2008. Towards a Framework for the Description and Evaluation of Dictionary Evaluation Criteria. Lexikos 18: 207-231.

Swanepoel, Piet. 2013. Evaluation of Dictionaries. Gouws, Rufus H., Ulrich Heid, Wolfgang Schweickard and Herbert Ernst Wiegand (Eds.). 2013: 587-596.

Swanepoel, Piet. 2015. The Design of Morphological/Linguistic data in L1 and L2 Monolingual Explanatory Dictionaries: A Functional and/or a Linguistic Approach? Lexikos 25.

Tarp, Sven. 2008. Lexicography in the Borderland between Knowledge and Non-Knowledge. General Lexicographical Theory with Particular Focus on Learner's Lexicography. Lexicographica. Series Maior 134. Tübingen: Max Niemeyer.

Tarp, Sven. 2009. Reflections on Lexicographical User Research. Lexikos 19: 275-296.

Tarp, Sven. 2013. Lexicographic Functions. Gouws, Rufus H., Ulrich Heid, Wolfgang Schweickard and Herbert Ernst Wiegand (Eds.). 2013: 460-468.

Tarp, Sven. 2014. Theory-Based Lexicographical Methods in a Functional Perspective: An Overview. Lexicographica 30: 58-76.

Tono, Yukio. 2001. Research on Dictionary Use in the Context of Foreign Language Learning. Focus on Reading Comprehension. Lexicographica. Series Maior 106. Tübingen: Max Niemeyer.

Tono, Yukio. 2011. Application of Eye-Tracking in EFL Learners' Dictionary Look-up Process Research. International Journal of Lexicography 24(1): 124-153. 
Töpel, Antje. 2014a. Methoden zur Erstellung von Bedeutungsparaphrasenangaben. Lexicographica 30: 291-319.

Töpel, Antje. 2014b. Review of Research into the Use of Electronic Dictionaries. Müller-Spitzer, Carolin (Ed.). 2014a: 13-54.

Wahrig, Gerhard. 1973. Anleitung zur grammatisch-semantischen Beschreibung lexikalischer Einheiten. Versuch eines Modells. Linguistische Arbeiten 8. Tübingen: Max Niemeyer.

Warnke, Ingo H. and Jürgen Spitzmüller. 2008. Methoden der Diskurslinguistik. Sprachwissenschaftliche Zugänge zur transtextuellen Ebene. Berlin/New York: De Gruyter.

Welker, Herbert Andreas. 2006. O uso de dicionários: Panorama geral das pesquisas empiricas. Brasilia: Thesaurus.

Welker, Herbert Andreas. 2013a. Empirical Research into Dictionary Use since 1990. Gouws, Rufus H., Ulrich Heid, Wolfgang Schweickard and Herbert Ernst Wiegand (Eds.). 2013: 531-540.

Welker, Herbert Andreas. 2013b. Methods in the Research of Dictionary Use. Gouws, Rufus H., Ulrich Heid, Wolfgang Schweickard and Herbert Ernst Wiegand (Eds.). 2013: 540-547.

Wiegand, Herbert Ernst. 1984. Prinzipien und Methoden historischer Lexikographie. Besch, Werner, Oskar Reichmann and Stefan Sonderegger (Eds.). 1984. Sprachgeschichte. Ein Handbuch zur Geschichte der deutschen Sprache und ihrer Erforschung: 557-620. Handbücher zur Sprachund Kommunikationswissenschaft 2.1. Berlin/New York: De Gruyter.

Wiegand, Herbert Ernst. 1985. Fragen zur Grammatik in Wörterbuchbenutzungsprotokollen. Ein Beitrag zur empirischen Erforschung der Benutzung einsprachiger Wörterbücher. Bergenholtz, Henning and Joachim Mugdan (Eds.). 1985. Lexikographie und Grammatik. Akten des Essener Kolloquiums zur Grammatik im Wörterbuch, 28-30.6.1984: 20-98. Lexicographica Series Maior 3. Tübingen: Max Niemeyer.

Wiegand, Herbert Ernst. 1987. Zur handlungstheorethischen Grundlegung der Wörterbuchbenutzungsforschung. Kučera, A., A. Rey, H.E. Wiegand and L. Zgusta (Eds.). 1987. Lexicographica 3: 178-227. Tübingen: Max Niemeyer.

Wiegand, Herbert Ernst. 1989. Aspekte der Makrostruktur im allgemeinen einsprachigen Wörterbuch: Alphabetische Anordnungsformen und ihre Probleme. Hausmann, Franz Josef, Oskar Reichmann, Herbert Ernst Wiegand en Ladislav Zgusta (Eds.). 1989: 371-409

Wiegand, Herbert Ernst. 1998a. Wörterbuchforschung. Untersuchungen zur Wörterbuchbenutzung, zur Theorie, Geschichte, Kritik und Automatisierung der Lexikographie. Volume 1. Berlin/New York: Walter de Gruyter.

Wiegand, Herbert Ernst (Ed.). 1998b. Perspektiven der pädagogischen Lexikographie des Deutschen. Untersuchungen anhand von Langenscheidts Großwörterbuch Deutsch als Fremdsprache. Lexicographica. Series Maior 86. Tübingen: Max Niemeyer.

Wiegand, Herbert Ernst. 2002a. Altes und Neues zur Mediostruktur in Printwörterbüchern. Lexicographica 18: 168-252.

Wiegand, Herbert Ernst (Ed.). 2002b. Perspektiven der pädagogischen Lexikographie des Deutschen II. Untersuchungen anhand des de Gruyter Wörterbuchs Deutsch als Fremdsprache. Lexicographica. Series Maior 110. Tübingen: Max Niemeyer.

Wiegand, Herbert Ernst. 2004. Lexikographisch-historische Einführung. Dornseiff, Franz. 2004: 9*91*. Berlin/New York: Walter de Gruyter.

Wiegand, Herbert Ernst. 2005. Angaben, funktionale Angabezusätze, Angabetexte, Angabestrukturen, Strukturanzeiger, Kommentare und mehr. Ein Beitrag zur Theorie der Wörterbuchform. Lexicographica 21: 202-379. 
Wiegand, Herbert Ernst. 2010. Zur Methodologie der Systematischen Wörterbuchforschung: Ausgewählte Untersuchungs- und Darstellungsmethoden für die Wörterbuchform. Lexicographica 26: 249-330.

Wiegand, Herbert Ernst. 2011. Funktionale Verweisartikelstrecken und Verweisartikelteilstrecken in Fachwörterbüchern vom Typ des Lern- und Konsultationswörterbuchs. Lexicographica 27: 299-311.

Wiegand, Herbert Ernst, Sandra Beer and Rufus H. Gouws. 2013. Textual Structures in Printed Dictionaries: An Overview. Gouws, Rufus H., Ulrich Heid, Wolfgang Schweickard and Herbert Ernst Wiegand (Eds.). 2013: 31-73.

Wiegand, Herbert Ernst and Sandra Beer. 2013. Access Structures in Printed Dictionaries. Gouws, Rufus H., Ulrich Heid, Wolfgang Schweickard and Herbert Ernst Wiegand (Eds.). 2013: 110-149.

Wiegand, Herbert Ernst and $\mathbf{M}^{\mathbf{a}}$ Teresa Fuentes Morán. 2010. Estructuras lexicográficas. Aspectos centrales de una teoría de la forma del diccionario. Colección Lexicografía 2. Granada: Ediciones Tragacanto.

Wiegand, Herbert Ernst and Rufus H. Gouws. 2013. Macrostructures in Printed Dictionaries. Gouws, Rufus H., Ulrich Heid, Wolfgang Schweickard and Herbert Ernst Wiegand (Eds.). 2013: 73-110.

Wiegand, Herbert Ernst and Maria Smit. 2013a. Microstructures in Printed Dictionaries. Gouws, Rufus H., Ulrich Heid, Wolfgang Schweickard and Herbert Ernst Wiegand (Eds.). 2013: 149-214.

Wiegand, Herbert Ernst and Maria Smit. 2013b. Mediostructures in Printed Dictionaries. Gouws, Rufus H., Ulrich Heid, Wolfgang Schweickard and Herbert Ernst Wiegand (Eds.). 2013: 214-253.

WLWF-I (2010) = Wiegand, Herbert Ernst, Michael Beißwenger, Rufus H. Gouws, Matthias Kammerer, Angelika Storrer and Werner Wolski (Eds.). 2010. Wörterbuch zur Lexikographie und Wörterbuchforschung/Dictionary of Lexicography and Dictionary Research. Volume 1, A-C. Berlin/ New York: Walter de Gruyter.

Wolski, Werner. 1989. Formen der Textverdichtung im allgemeinen einsprachigen Wörterbuch. Hausmann, Franz Josef, Oskar Reichmann, Herbert Ernst Wiegand and Ladislav Zgusta (Eds.). 1989: 956-967. 